\title{
Antiviral Mechanism of Tea Polyphenols on Porcine Reproductive and Respiratory Syndrome Virus
}

\author{
Wenjuan Dong \\ Sun Yat-Sen University \\ Xun Wang \\ Sun Yat-Sen University \\ Xiaoxiao Zhang \\ Sun Yat-Sen University \\ Zhenbang Zhu \\ Sun Yat-Sen University \\ Yaosheng Chen \\ Sun Yat-Sen University \\ Xiaohong Liu \\ Sun Yat-Sen University
}

Chunhe Guo ( $\nabla$ guochunh@mail.sysu.edu.cn )

Sun Yat-Sen University https://orcid.org/0000-0002-7859-1985

Research article

Keywords: PRRSV, Tea polyphenols, Antiviral, Cytokine

Posted Date: September 10th, 2020

DOI: https://doi.org/10.21203/rs.3.rs-39019/v1

License: (c) (i) This work is licensed under a Creative Commons Attribution 4.0 International License.

Read Full License 


\section{Abstract}

Background: Neither inactivated vaccine nor attenuated vaccine can effectively prevent and control the infection and spread of porcine reproductive and respiratory syndrome virus (PRRSV). Therefore, it is necessary to broaden new horizons and to conceive effective preventive strategies. Tea polyphenols (TPP) are polyphenol in tea. The main components of TPP are catechins and their derivatives. TPP has many physiological activities and has certain antiviral and antifungal effects. But whether TPP owns anti-PRRSV activity remains unclear.

Results: We found that TPP effectively inhibited PRRSV replication in Marc- 145 cells by suppressing viral attachment and internalization. TPP exhibited a potent anti-PRRSV effect regardless of its pre-treatment or post-treatment. In addition, we demonstrated that TPP restrained PRRSV-induced p65 entry into the nucleus to suppress the activation of the NF-KB signaling pathway, which ultimately leads to the inhibition of the expression of inflammatory cytokines. Furthermore, TPP limited the synthesis of viral non-structural protein 2 (nsp2), the core component of viral replication transcription complexes, which may contribute to the inhibition of viral RNA replication.

Conclusions: TPP has the potential to develop into an effective antiviral agent for PRRSV prevention and control in the future.

\section{Background}

Porcine reproductive and respiratory syndrome virus (PRRSV) is one of the most important pathogens that continuously impacts the swine industry worldwide. PRRSV was first recognized in the late 1980s in North America and Europe [1, 2]. It belongs to the order Nidovirales, family Arteriviridae, which is a small, enveloped virus (diameter about $65 \mathrm{~nm}$ ) containing a single-stranded RNA genome of positive polarity. Its genome is about $15 \mathrm{~kb}$ in length which contains at least 11 open reading frames [3]. The virus mainly grows in porcine alveolar macrophages and causes acute pneumonia and reproductive and respiratory problems in pigs [4-6].

According to the current knowledge, PRRSV mutates rapidly at an estimated rate of $3.29 \times 10^{-3}$ substitutions per nucleotide per year, developing rapidly growing evolutionary strains [7, 8]. Due to its high antigenic variability and poorly understood in its immunopathogenesis, there is currently no effective vaccine or treatment to control PRRSV infection [9].

According to the theory of traditional Chinese medicine, more and more natural ingredients have been proved to have the functions of disease prevention, health care and antivirus [10-12]. Tea polyphenol (TPP) is the general term of polyphenols in tea leaves. The main components of TPP are catechin and its derivatives. TPP has many physiological activities, such as anti-oxidation, anti-radiation, anti-aging, lowering blood lipids, lowering blood sugar, and inhibiting bacteria and enzymes. It is a compound with polyphenolic structural properties, such as catechins and anthocyanins. TPP is the main component of green tea soup, which has certain antiviral and antifungal effects [13-15]. It was pointed out in the past 
investigations that epigallocatechin gallate (EGCG) which accounts for 60 to $80 \%$ of TPP has already been reported for its antiviral effect on several viruses: hepatitis $C$ virus, chikungunya virus, hepatitis $B$ virus, and Zika virus [16-20].

However, whether TPP has an inhibitory effect on PRRSV infection and replication remains unknown. Here, we demonstrated that TPP potently inhibited PRRSV infection in Marc-145 cells in a dosedependent manner. The mechanism of PRRSV inhibition by TPP was also investigated. TPP inhibited the attachment, internalization and replication stages of PRRSV life cycle, but not release. TPP could inhibit p65 transport into the nucleus, thus suppressing the activation of the NF-KB signaling pathway, which ultimately results in the inhibition of the expression of inflammatory cytokine induced by PRRSV infection. In addition, TPP was capable of blocking the synthesis of viral non-structural protein 2 (nsp2), the core component of replication transcription complexes (RTC), which then leads to the suppression of the translation and assembly of viral proteins.

\section{Results}

\section{TPP can inhibit the replication of PRRSV}

To identify the antiviral activity of TPP against PRRSV, we first used the alamarBlue ${ }^{\circledR}$ assay to test the cytotoxicity of TPP in Marc-145 cells. As shown in Figure 1A, with the increased concentrations of TPP, the cell viability rate (\%) was not affected, TPP at the concentration of no higher than $100 \mu \mathrm{g} / \mathrm{mL}$ showed no cytotoxic effect. Next, we examined the anti-PRRSV effect of TPP by immunofluorescence microscopy and qRT-PCR at $36 \mathrm{~h}$ post infection (hpi). As shown in Figure 1B and C, PRRSV was significantly inhibited by TPP in a dose-dependent manner. The green fluorescence counting by IFA image was significantly reduced. We further tested the effect of TPP on PRRSV infection at different time points. As shown in Figure 1D and E, treatment with TPP in cells resulted in a significant reduction of the mRNA and protein levels of PRRSV N. We further used PRRSV strain CHR6 at different MOls to infect Marc-145 cells. TPP still exhibited incredible and strong anti-PRRSV activity (Figure $1 F$ and $G$ ). These results indicate that TPP has potent inhibition against PRRSV infection.

\section{Pre-treatment and post-treatment of TPP show a potent inhibitory effect on PRRSV infection}

Since TPP plays a powerful role in inhibiting PRRSV (Figure 1), we next treated Marc-145 cells with TPP before or after PRRSV infection. The results showed that PRRSV was effectively inhibited when cells were pre-treated with TPP for $2 \mathrm{~h}$ and then infected with PRRSV for $24 \mathrm{~h}$ (Figure 2A and C). In post-treatment assay, TPP also showed a potent inhibitory effect on the mRNA and protein levels of PRRSV N. These data demonstrate that TPP restrains PRRSV replication regardless of its pre-treatment or post-treatment.

\section{TPP blocks viral attachment, internalization and replication, but not release}

Since both pre-treatment and post-treatment of TPP play an effective inhibitory effect on virus replication, we then explored which stage(s) of viral infection was/were interrupted by TPP treatment. To investigate 
this, we designed viral attachment, entry, replication and release assays as described in Figure 3A. For virus binding, Marc-145 cells were infected with PRRSV-CHR6 $(\mathrm{MOI}=0.6)$ in the presence or absence of TPP for $2 \mathrm{~h}$ at $4{ }^{\circ} \mathrm{C}$, which allows virus binding but not internalization (Figure $3 \mathrm{~A}$, treatment $\mathrm{B}$ ), then cultured for $24 \mathrm{~h}$ at $37^{\circ} \mathrm{C}$. As shown in Figure 3B囚TPP treatment showed an inhibitory effect on PRRSV binding to Marc-145 cells. To examine whether TPP may also affect the internalization of PRRSV, virusinfected Marc-145 cells were treated with TPP for 2 or $4 \mathrm{~h}$ (Figure 3A, treatment C). As shown in Figure 3C, virus replication was significantly inhibited, suggesting that TPP also inhibits PRRSV internalization.

For replication, Marc-145 cells were infected with PRRSV for $6 \mathrm{~h}$ at $37^{\circ} \mathrm{C}$ to realize normal virus replication. The infected cells were then treated with TPP for 2 or $4 \mathrm{~h}$ (Figure $3 \mathrm{~A}$, treatment $\mathrm{D}$ ), and washed with PBS to remove TPP. Cells were collected at $24 \mathrm{hpi}$. As shown in Figure 3D, TPP treatment significantly reduced the viral $\mathrm{N}$ protein level, suggesting that TPP inhibits the replication stage of PRRSV. We further examined whether TPP could affect PRRSV release (Figure 3A, treatment E). TPP had no effects on the release phase of PRRSV infection (Figure 3E).

\section{TPP treatment reduces the expression of p65 and impairs p65 transport into the nucleus after PRRSV infection}

To investigate whether the NF-KB signal pathway is affected by TPP, the location of NF-KB p65 was tested in Marc-145 cells treated with TPP. As shown in Figure 4A, TPP significantly inhibited the mRNA expression of NF-kB p65 induced by PRRSV infection. PRRSV infection led to the translocation of p65 into the cell nucleus, resulting in the activation of the NF-KB pathway. However, upon TPP treatment, red fluorescence representing p 65 located in the nucleus was drastically reduced in virus-infected cells (Figure 4B). These data show that TPP inhibits p65 transport into the nucleus which was caused by PRRSV infection, thus inhibiting the activation of NF-KB signaling pathway.

\section{TPP treatment decreases cytokine expression induced by PRRSV in Marc-145 cells}

Since TPP inhibits the activation of NF-KB signaling pathway, we speculated that TPP could limit PRRSVinduced cytokine expression. To demonstrate the hypothesis, we explored the effect of TPP on the expression of cytokines such as IFN- $\beta$, IL-6, IL-8 and TNF-a, which are known to be related to the host antiviral and inflammatory reactions. Upon TPP treatment, the mRNA levels of IFN- $\beta$, IL-6, IL-8 and TNF- $a$ were significantly diminished in PRRSV-infected Marc-145 cells (Figure 5A-D). Compared to the mocktreated cells, the cytokine expression displayed a comparable level in cells treated with TPP alone. These data suggest that TPP may restrain PRRSV replication via inhibiting virus-induced expression of cytokines.

\section{TPP inhibits the synthesis of PRRSV nsp2, the core component of viral RTC.}

Since TPP effectively inhibits the replication of PRRSV, we speculated that the inhibition may be attributed to its effect on the assembly of replication transcription complexes, in which viral nsp2 plays a crucial role. To validate the hypothesis, we tested the expression of viral nsp2 upon TPP treatment in 
Marc-145 cells. As shown in Figure 6, compared to the cells with PRRSV treatment alone, green fluorescence representing nsp2 expression was remarkably reduced in the presence of TPP in Marc-145 cells, which suggests that TPP directly inhibits the synthesis of PRRSV nsp2.

\section{Discussion}

PRRSV has spread rapidly all over the world, which has lasted for many years. In recent years, the prevention and control of the virus have become more and more complex, the diversity of virus strains has been increasing, and new virus strains are emerging. Because of its great variability and persistent infection, PRRSV is difficult to control [21-23]. Moreover, due to the abuse of vaccines, many newly emerged PRRSV are caused not by wild-type strains, but by vaccine viruses [24, 25]. In recent years, there have been some new vaccines with specific adjuvants, but they have little protective effect. Some drugs, such as herbal extracts, compounds, siRNA, microRNA and neutralizing antibodies, have been shown to inhibit PRRSV replication in vitro [26-28]. However, their antiviral persistence is not clear, and it's far from being applied to the actual pig industry.

In our study, TPP inhibits the replication of PRRSV in multiple ways. Likewise, other polyphenols have also been described to present antiviral activity, such as proanthocyanidin A2 and theaflavin $[29,30]$. Previous reports also indicate that replication of PRRSV in Marc-145 cells is inhibited by EGCG [20], which accounts for 60 to $80 \%$ of TPP. However, TPP is the total content of polyphenols in tea, showing better antiviral properties.

We conclude TPP has multiple potential mechanisms of viral inhibition as described in Fig. 7. On the one hand, TPP blocks the attachment and internalization of PRRSV, or inhibits the assembly of viral RTC after virions enter cells during virus life cycle. On the other hand, TPP is capable of restraining PRRSV-induced translocation of NF-KB p65 into the nucleus, thereby suppressing the expression of cytokines, which may contribute to its inhibition of PRRSV.

From the effects of pre-treatment and post-treatment of TPP on PRRSV replication, the effect of the pretreatment approach seems to be better. However, there are no inhibitory effects on PRRSV replication during viral release period upon TPP treatment, which may explain that the anti-PRRSV activity of TPP pre-treatment is more effective than that of post-treatment. The middle region of viral nsp2 is highly heterogeneous and responsible for size variation among PRRSV strains [31, 32]. Variations might contribute to viral fitness by regulating viral mRNA synthesis, suggesting that viral nsp2 is a critical component of viral RTC. In addition, Assembly of PRRSV RTC requires a network of viral nsps including nsp2 $[33,34]$. In this study, we show that TPP inhibits the synthesis of nsp2, thereby blocking the formation of viral RTC.

\section{Conclusion}


In conclusion, our study demonstrates that TPP shows a potent antiviral effect on PRRSV infection via targeting attachment process of viral life cycle and down-regulating virus-induced inflammatory cytokines in infected cells. These results indicate that TPP has the potential to develop into a novel drug to prevent and control PRRSV infection in the future.

\section{Methods}

\section{Cells and viruses}

Marc-145 cells (China Center for Type Culture Collection, China), an immortalized cell line derived from African green monkey kidney cells, were cultured in Dulbecco's modified Eagle's medium (DMEM) (Corning, USA) containing 10\% fetal bovine serum (FBS) (PAN, Germany), which are permissive to PRRSV replication and are commonly used in laboratories. PRRSV strain CHR6 (Classical North American type PRRSV strain) was provided by Dr. Guihong Zhang from South China Agricultural University, and PRRSVEGFP, a recombinant virus showing growth replication characteristics similar to those of the wild-type virus in the infected cells, was gifted by Dr. Shuqi Xiao from Northwest A\&F University. CHR6 and PRRSVEGFP were used to infect Marc-145 cells. The virus strains were propagated in Marc-145 cells and titrated as $50 \%$ tissue culture infective dose $\left(\mathrm{TCID}_{50}\right)$.

\section{Cytotoxicity assay}

The cytotoxicity of TPP was detected with the alamarBlue ${ }^{\circledR}$ assay (Invitrogen, USA) according to the manufacturer's instructions. Marc-145 cells $\left(1 \times 10^{4} /\right.$ well) were seeded in 96 - well plates, different concentrations of TPP were added in DMEM medium when cells grew to $60-70 \%$ confluence. After incubation for $48 \mathrm{~h}$ in Marc-145 cells, $10 \mu \mathrm{L}$ of alamarBlue ${ }^{\circledR}$ was added to each well, and incubated for another $3 \mathrm{~h}$. At last, the fluorescence value was detected using Multi-Mode Reader (Synergy2, BioTek, USA) at the absorbance of $570 \mathrm{~nm}$.

\section{Quantitative real-time reverse-transcription polymerase chain reaction (qRT-PCR)}

To detect the relative expression of PRRSV ORF7 and cytokines, qRT-PCR was performed. RNA was extracted from cultured cells using TRIzol reagent (Magen, China). Reverse Transcription System (A3500, Promega, USA) was used for reverse transcription in $20 \mu \mathrm{L}$ reaction volume following the manufacturer's instructions. The reverse-transcription primers were Oligo (dT) 15 primer (C110A, Promega, USA) and Random primer (C118A, Promega, USA). Reverse transcription products were amplified by a LightCycler 480 Real-Time PCR System (LC480, Roche, Switzerland) using $2 \times$ RealStar Green Power Mixture (GenStar, China). The primers are listed in Table 1. qRT-PCR reaction system was run under the following conditions: $95^{\circ} \mathrm{C}$ for $10 \mathrm{~min}$, then $95^{\circ} \mathrm{C}$ for $15 \mathrm{~s}, 60^{\circ} \mathrm{C}$ for $1 \mathrm{~min}$ and $72{ }^{\circ} \mathrm{C}$ for $30 \mathrm{~s}$ went through 40 cycles, finally $72{ }^{\circ} \mathrm{C}$ for $10 \mathrm{~min}$. Data were normalized to GAPDH in each individual sample. The $2-\Delta \Delta \mathrm{Ct}$ method was used to calculate relative expression changes. Relative expression (fold changes) was compared to mock infected cells. 


\section{Western blot}

Six-well-plate cell samples $\left(2 \times 10^{6} /\right.$ well) were harvested in cell lysis buffer (Beyotime, China) containing PMSF (Beyotime, China). Processed samples were subjected to $12 \%$ sodium dodecyl sulfatepolyacrylamide gel electrophoresis (SDS-PAGE) and transferred onto a polyvinyl difluoride (PVDF) membrane (Roche, USA). Then the membranes were blocked with 5\% BSA (Ruishu, China) in TBST (20 Mm Tris-HCl PH8.0, $150 \mathrm{mM} \mathrm{NaCl}, 0.05 \%$ Tween 20) for $1 \mathrm{~h}$ at $37^{\circ} \mathrm{C}$. After blocking they were incubated with an anti-PRRSV N protein monoclonal antibody (1:1000 dilution, Jeno Biotech, Inc., Republic of Korea), and an anti-glyceraldehyde phosphate dehydrogenase (GAPDH) antibody (1:1000 dilution, Cell Signaling Technology, USA) overnight at $4^{\circ} \mathrm{C}$. After washing three times with TBST, membranes were incubated with an anti-mouse IgG, HRP-linked antibody or anti-rabbit IgG, HRP-linked antibody (1:1000 dilution, Cell Signaling Technology, USA) for $1 \mathrm{~h}$ at $37^{\circ} \mathrm{C}$. The antibody signals were exposed using an enhanced chemiluminescence $(E C L)$ reagent (Fdbio Science, China).

\section{Antiviral assay}

Cells were seeded in six-well plates and grown to $70-80 \%$ confluence. There were two approaches to analyze the antiviral effect of TPP. (I) Pre-treatment: Cells were pre-treated with different concentrations of TPP $(0,50$ and $100 \mu \mathrm{g} / \mathrm{ml})$ for $2 \mathrm{~h}$, PRRSV-CHR6 was then added and cultured for $36 \mathrm{~h}$. (II) Posttreatment: Cells were inoculated with PRRSV-CHR6 for $4 \mathrm{~h}$, then the inoculum was removed and TPP $(0$, 50 and $100 \mu \mathrm{g} / \mathrm{ml}$ ) was added to cells for $36 \mathrm{~h}$.

\section{Viral attachment, entry, replication and release assays}

For attachment assay, cells were cooled for $2 \mathrm{~h}$ at $4{ }^{\circ} \mathrm{C}$, and then infected with PRRSV-CHR6 at a multiplicity of infection (MOI) of 0.6 in the presence of different concentrations of TPP $(0,25$ and 50 $\mu \mathrm{g} / \mathrm{ml}$ ) for $2 \mathrm{~h}$ at $4{ }^{\circ} \mathrm{C}$. After rinsing with cold PBS three times, cells were replenished with fresh DMEM containing $2 \% \mathrm{FBS}$ for $24 \mathrm{~h}$ at $37^{\circ} \mathrm{C}$. The cells were collected for western blot analysis so that we could determine the effect of TPP on viral attachment. As for entry assay, cells were inoculated with PRRSVCHR6 ( $\mathrm{MOI}=0.6)$ for $2 \mathrm{~h}$ at $4{ }^{\circ} \mathrm{C}$. After binding to the cell surface, cells were washed with PBS three times and cultured at $37^{\circ} \mathrm{C}$ for 2 or $4 \mathrm{~h}$ in the presence of various concentrations of $\operatorname{TPP}(0,25$, and $50 \mu \mathrm{g} / \mathrm{mL})$. Cells were then washed with PBS and incubated for another $24 \mathrm{~h}$ at $37^{\circ} \mathrm{C}$. The cells were collected for western blot analysis so that we could determine the effect of TPP on viral internalization. As for replication assay, cells were inoculated with PRRSV-CHR6 $(\mathrm{MOI}=0.6)$ at $37^{\circ} \mathrm{C}$ for $6 \mathrm{~h}$, then various concentrations of $\operatorname{TPP}(0,25$, and $50 \mu \mathrm{g} / \mathrm{mL})$ were added for 2 or $4 \mathrm{~h}$. Cells were then washed with PBS and incubated for an additional $24 \mathrm{~h}$ at $37^{\circ} \mathrm{C}$. The cells were collected for western blot analysis so that we could determine the effect of TPP on viral replication. For release assay, cells were incubated with PRRSV-CHR6 $(\mathrm{MOI}=0.6)$ for $24 \mathrm{~h}$ at $37^{\circ} \mathrm{C}$. After that, cells were rinsed with PBS three times and TPP at different concentrations was added to the cells for $3 \mathrm{~h}$ at $37^{\circ} \mathrm{C}$. At last, cells were collected for western blot analysis to detect the PRRSV N protein expression.

\section{Immunofluorescence Assay (IFA)}


Cells were fixed by $4 \%$ paraformaldehyde for 15 min. After permeabilized with $0.5 \%$ Triton X-100 for 15 min at room temperature (RT), cells were blocked with $1 \%$ bovine serum albumin (BSA) for 30 min and then incubated with a rabbit monoclonal antibody against the p65-protein (1:500 dilution, Cell Signaling Technology) or an antibody against PRRSV nsp2 (a gift from Dr. Hanchun Yang, China Agricultural University, 1:1000) at $4{ }^{\circ} \mathrm{C}$ overnight. Cells were then incubated with an anti-rabbit secondary antibody conjugated with Alexa Fluor ${ }^{\circledR} 555$ or 488 (Cell Signaling Technology, MA, USA) at 1:1000 dilution for $2 \mathrm{~h}$. Nuclei were stained using DAPI (1:1000; Cell Signaling Technology). Cells were examined by fluorescence microscopy (Nikon, Japan).

\section{Statistical analysis}

All experiments were performed with at least three independent replicates. Student's t-test and one-way ANOVA were used to analyze the data. Statistical analysis was performed using SPSS 17.0 and GraphPad Prism 6.0. $P<.05$ was considered to be significant.

\section{Abbreviations}

PRRSV

Porcine reproductive and respiratory syndrome virus; TPP:Tea polyphenols; nsp2:non-structural protein 2; RTC:replication transcription complexes.

\section{Declarations}

\section{Ethics approval and consent to participate}

Not applicable.

\section{Consent for publication}

Not applicable.

\section{Availability of data and materials}

All data analyzed during this study are included in this published article. The raw data are available from the corresponding author upon reasonable request.

\section{Competing interests}

The authors declare that they have no competing interests.

\section{Funding}

This work was supported by Science and Technology Planning Project for Guangzhou (201804020039) and National Natural Science Foundation of China (31601917). Neither of the funders were involved in 
designing and conducting of the study, collection, analysis and interpretation of data, or writing of the manuscript.

\section{Authors' contributions}

CG conceived the project. WD designed the study, performed the experiments, and analyzed the data. XW drafted the manuscript. WD, WX, XZ, ZZ, YC, XL and CG coordinated the study. CG, XL and YC contributed to the interpretation of the data and took part in the critical revision of the manuscript. All authors have read and approved the final manuscript.

\section{Acknowledgements}

Not applicable.

\section{Authors' information}

State Key Laboratory of Biocontrol, School of Life Sciences, Sun Yat-sen University, North Third Road, Guangzhou Higher Education Mega Center, Guangzhou, Guangdong 510006, PR China.

\section{References}

1. Lunney JK, Benfield DA, Rowland RR. Porcine reproductive and respiratory syndrome virus: an update on an emerging and re-emerging viral disease of swine. Virus Res. 2010;154(1-2):1-6.

2. Neumann EJ, Kliebenstein JB, Johnson CD, Mabry JW, Bush EJ, Seitzinger AH, et al. Assessment of the economic impact of porcine reproductive and respiratory syndrome on swine production in the United States. J Am Vet Med Assoc. 2005;227(3):385-92.

3. Fang Y, Snijder EJ. The PRRSV replicase: exploring the multifunctionality of an intriguing set of nonstructural proteins. Virus Res. 2010;154(1-2):61-76.

4. Cho J, Dee S. Porcine reproductive and respiratory syndrome virus. Theriogenology. 2006;66(3):65562.

5. Hanada K, Suzuki Y, Nakane T, Hirose O, Gojobori T. The origin and evolution of porcine reproductive and respiratory syndrome viruses. Mol Biol Evol. 2005;22(4):1024-31.

6. Baron T, Albina E, Leforban Y, Madec F, Guilmoto H, Plana Duran J, et al. Report on the first outbreaks of the porcine reproductive and respiratory syndrome (PRRS) in France. Diagnosis and viral isolation. Ann Rech Vet. 1992;23(2):161-6.

7. Song J, Shen D, Cui J, Zhao B. Accelerated evolution of PRRSV during recent outbreaks in China. Virus Genes. 2010;41(2):241-5.

8. Li Y, Wang X, Bo K, Wang X, Tang B, Yang B, et al. Emergence of a highly pathogenic porcine reproductive and respiratory syndrome virus in the Mid-Eastern region of China. Vet J. 2007;174(3):577-84. 
9. Chand RJ, Trible BR, Rowland RR. Pathogenesis of porcine reproductive and respiratory syndrome virus. Curr Opin Virol. 2012;2(3):256-63.

10. Koehn FE, Carter GT. The evolving role of natural products in drug discovery. Nat Rev Drug Discov. 2005;4(3):206-20.

11. Zhou ZD, Xie SP, Saw WT, Ho PGH, Wang H, Lei Z, et al. The Therapeutic Implications of Tea Polyphenols Against Dopamine (DA) Neuron Degeneration in Parkinson's Disease (PD). Cells. 2019;8(8).

12. Chen T, Yang CS. Biological fates of tea polyphenols and their interactions with microbiota in the gastrointestinal tract: implications on health effects. Crit Rev Food Sci Nutr. 2019:1-19.

13. Nath S, Bachani M, Harshavardhana D, Steiner JP. Catechins protect neurons against mitochondrial toxins and HIV proteins via activation of the BDNF pathway. J Neurovirol. 2012;18(6):445-55.

14. Li QR, Luo JL, Zhou ZH, Wang GY, Chen R, Cheng S, et al. Simplified recovery of enzymes and nutrients in sweet potato wastewater and preparing health black tea and theaflavins with scrap tea. Food Chem. 2018;245:854-62.

15. Majidinia M, Bishayee A, Yousefi B. Polyphenols: Major regulators of key components of DNA damage response in cancer. DNA Repair (Amst). 2019;82:102679.

16. Ciesek S, von Hahn T, Colpitts CC, Schang LM, Friesland M, Steinmann J, et al. The green tea polyphenol, epigallocatechin-3-gallate, inhibits hepatitis C virus entry. Hepatology. 2011;54(6):194755 .

17. Huang HC, Tao MH, Hung TM, Chen JC, Lin ZJ, Huang C. (-)-Epigallocatechin-3-gallate inhibits entry of hepatitis B virus into hepatocytes. Antiviral Res. 2014;111:100-11.

18. Weber C, Sliva K, von Rhein C, Kummerer BM, Schnierle BS. The green tea catechin, epigallocatechin gallate inhibits chikungunya virus infection. Antiviral Res. 2015;113:1-3.

19. Carneiro BM, Batista MN, Braga ACS, Nogueira ML, Rahal P. The green tea molecule EGCG inhibits Zika virus entry. Virology. 2016;496:215-8.

20. Ge M, Xiao Y, Chen H, Luo F, Du G, Zeng F. Multiple antiviral approaches of (-)-epigallocatechin-3gallate (EGCG) against porcine reproductive and respiratory syndrome virus infection in vitro. Antiviral Res. 2018;158:52-62.

21. Murtaugh MP, Stadejek T, Abrahante JE, Lam TT, Leung FC. The ever-expanding diversity of porcine reproductive and respiratory syndrome virus. Virus Res. 2010;154(1-2):18-30.

22. Stadejek T, Stankevicius A, Murtaugh MP, Oleksiewicz MB. Molecular evolution of PRRSV in Europe: current state of play. Vet Microbiol. 2013;165(1-2):21-8.

23. Zhang X, Li Y, Xiao S, Yang X, Chen X, Wu P, et al. High-frequency mutation and recombination are responsible for the emergence of novel porcine reproductive and respiratory syndrome virus in northwest China. Arch Virol. 2019;164(11):2725-33.

24. Toman M, Celer V, Kavanova L, Leva L, Frolichova J, Ondrackova P, et al. Dynamics and Differences in Systemic and Local Immune Responses After Vaccination With Inactivated and Live Commercial 
Vaccines and Subsequent Subclinical Infection With PRRS Virus. Front Immunol. 2019;10:1689.

25. Rao X, Huang X, Zhou Z, Lin X. An improvement of the $2^{\wedge}$ (-delta delta CT) method for quantitative real-time polymerase chain reaction data analysis. Biostat Bioinforma Biomath. 2013;3(3):71-85.

26. Du T, Nan Y, Xiao S, Zhao Q, Zhou EM. Antiviral Strategies against PRRSV Infection. Trends Microbiol. 2017;25(12):968-79.

27. Han J, Zhou L, Ge X, Guo X, Yang H. Pathogenesis and control of the Chinese highly pathogenic porcine reproductive and respiratory syndrome virus. Vet Microbiol. 2017;209:30-47.

28. Ma SC, Du J, But PP, Deng XL, Zhang YW, Ooi VE, et al. Antiviral Chinese medicinal herbs against respiratory syncytial virus. J Ethnopharmacol. 2002;79(2):205-11.

29. Zhang $M$, Wu Q, Chen Y, Duan M, Tian G, Deng X, et al. Inhibition of proanthocyanidin A2 on porcine reproductive and respiratory syndrome virus replication in vitro. PLoS One. 2018;13(2):e0193309.

30. de Oliveira A, Prince D, Lo CY, Lee LH, Chu TC. Antiviral activity of theaflavin digallate against herpes simplex virus type 1. Antiviral Res. 2015;118:56-67.

31. Allende R, Lewis TL, Lu Z, Rock DL, Kutish GF, Ali A, et al. North American and European porcine reproductive and respiratory syndrome viruses differ in non-structural protein coding regions. $J$ Gen Virol. 1999;80 ( Pt 2):307-15.

32. Kappes MA, Miller CL, Faaberg KS. Highly divergent strains of porcine reproductive and respiratory syndrome virus incorporate multiple isoforms of nonstructural protein 2 into virions. J Virol. 2013;87(24):13456-65.

33. Nan H, Lan J, Tian M, Dong S, Tian J, Liu L, et al. The Network of Interactions Among Porcine Reproductive and Respiratory Syndrome Virus Non-structural Proteins. Front Microbiol. 2018;9:970.

34. Song J, Gao P, Kong C, Zhou L, Ge X, Guo X, et al. The nsp2 Hypervariable Region of Porcine Reproductive and Respiratory Syndrome Virus Strain JXwn06 Is Associated with Viral Cellular Tropism to Primary Porcine Alveolar Macrophages. J Virol. 2019;93(24).

\section{Tables}


Table 1

List of the primers used in this study.

\begin{tabular}{|c|c|}
\hline Primer $^{a}$ & Sequence $\left(5^{\prime}-3^{\prime}\right)^{b}$ \\
\hline $\mathrm{N}-\mathrm{F}$ & AAAACCAGTCCAGAGGCAAG \\
\hline $\mathrm{N}-\mathrm{R}$ & CGGATCAGACGCACAGTATG \\
\hline GAPDH-F & TGACAACAGCCTCAAGATCG \\
\hline GAPDH-R & GTCTTCTGGGTGGCAGTGAT \\
\hline IFN-a-F & AGAGCCTCCTGCACCAGTTCT \\
\hline IFN-a & -R TCAСТССТTCTTCCTG \\
\hline IFN- $\beta-F$ & GCAATTGAATGGAAGGCTTGA \\
\hline IFN- $\beta-R$ & CAGCGTCCTCCTTCTGGAACT \\
\hline IL-6-F & AGAGGCACTGGCAGAAAAC \\
\hline IL-6-R & TGCAGGAACTGGATCAGGAC \\
\hline IL-8-F & CACTGTGAAAATTCAGAAATCATTGTTA \\
\hline IL-8-R & СTTCACAAATACCTGCACAАССTTC \\
\hline TNF-a-F & TCTGTCTGCTGCACTTTGGAGTGA \\
\hline TNF-a-R & TTGAGGGTTTGCTACAACATGGGC \\
\hline
\end{tabular}

\section{Figures}


A

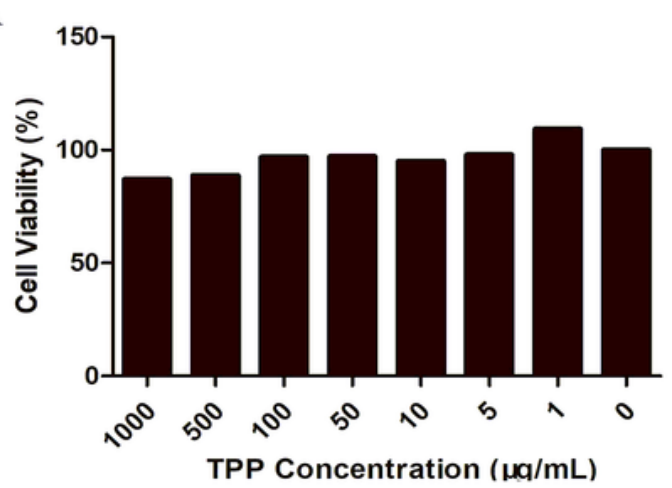

$\mathrm{C}$

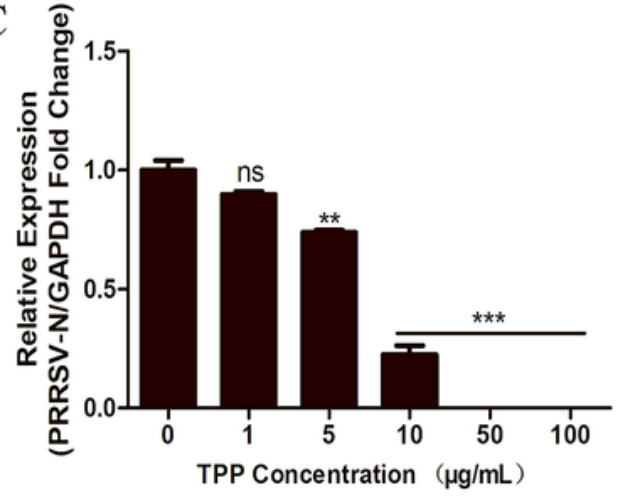

B
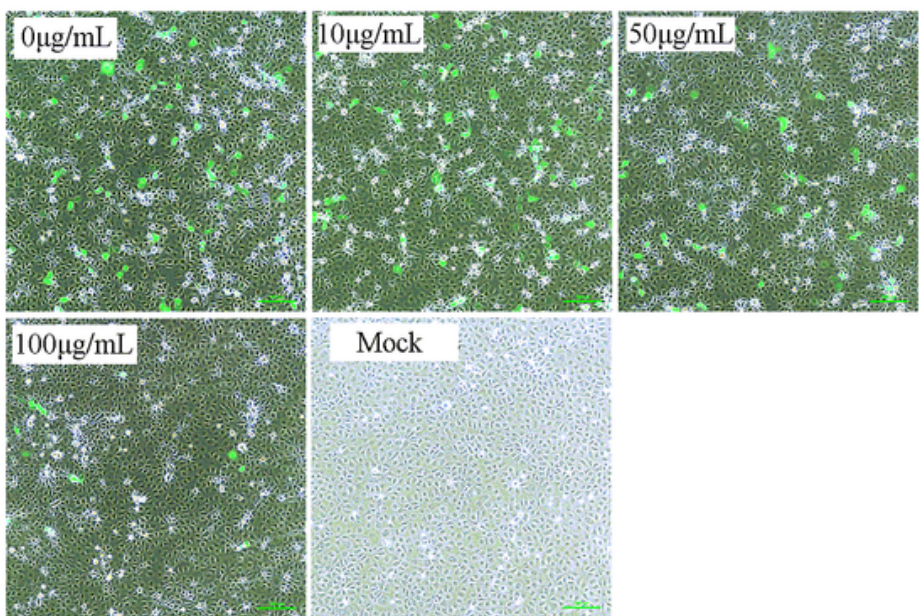

Mock

PRRSV+TPP $(50 \mu \mathrm{g} / \mathrm{mL})$

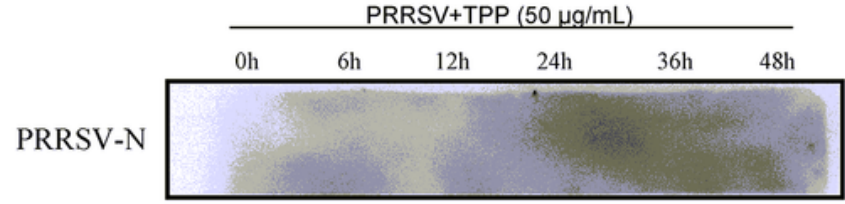

GAPDH

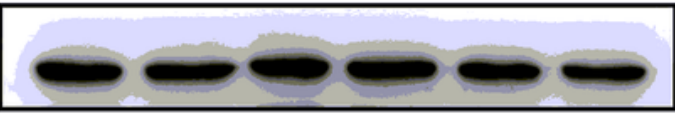

$\mathrm{D}$
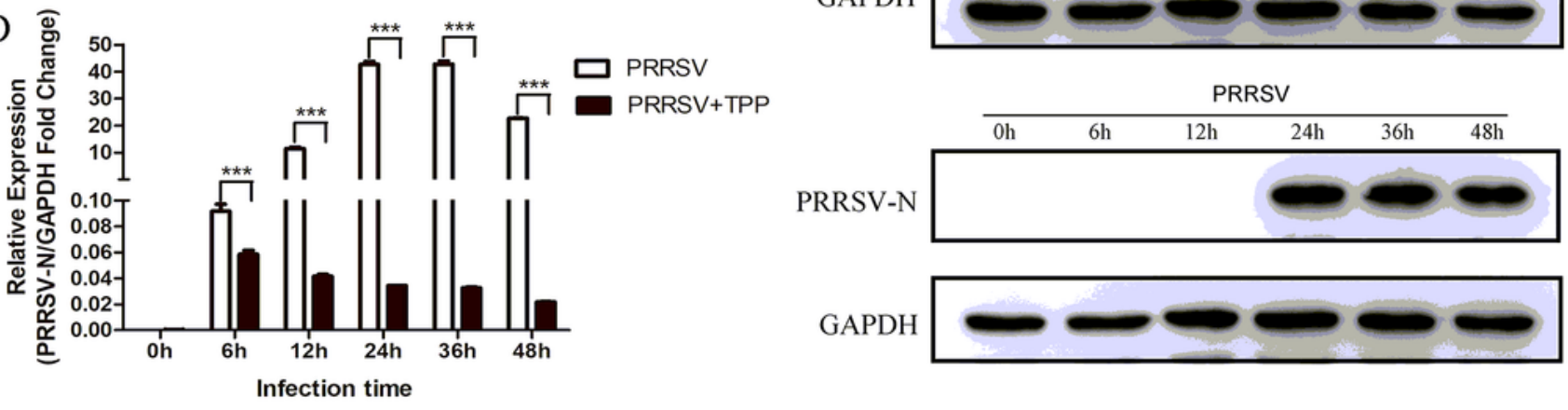

F

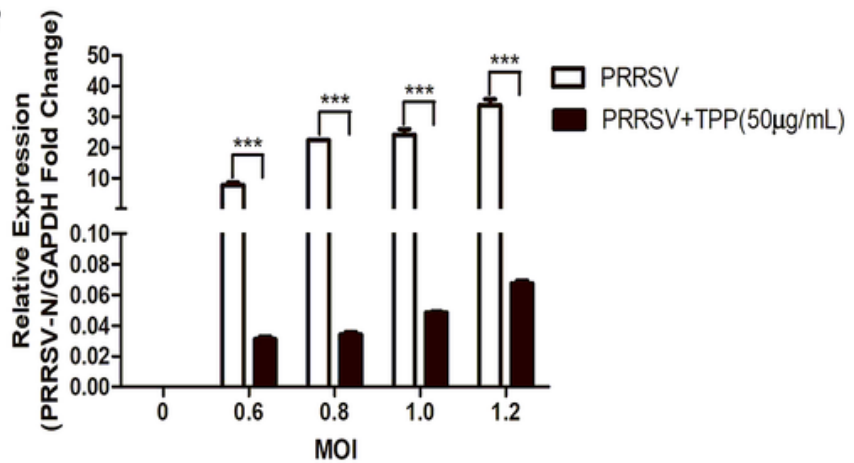

G

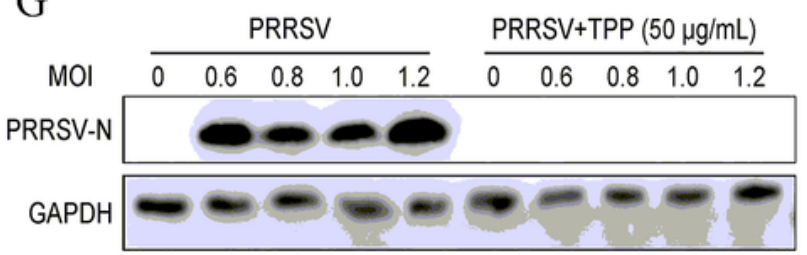

\section{Figure 1}

TPP restrains the infection and replication of PRRSV in Marc-145 cells. (A) The cytotoxicity of TPP was measured by the alamarBlue ${ }^{\circledR}$ assay. Marc- 145 cells were treated with TPP at indicated concentrations for $48 \mathrm{~h}$ and cell viability assay was performed. (B) Marc-145 cells were infected with PRRSV-EGFP (MOI $=0.6$ ) in the presence of different concentrations of TPP for $36 \mathrm{~h}$ and then were fixed for fluorescence microscope examination. Scale bar, $100 \mu \mathrm{m}$. (C) Marc-145 cells were infected with PRRSV-CHR6 (MOI = 
0.6) in the presence of different concentrations of TPP for $36 \mathrm{~h}$. The mRNA expression of viral ORF7 (PRRSV N) was detected by qRT-PCR. (D and E) Marc-145 cells were infected with PRRSV-CHR6 (MOI = $0.6)$ in the presence or absence of TPP for different time points, the mRNA level of viral ORF7 (PRRSV N) was detected by qRT-PCR (D) and PRRSV N protein was determined by western blot (E). ( $F$ and G) Marc145 cells were infected with PRRSV-CHR6 at different MOls in the presence or absence of TPP for $36 \mathrm{~h}$, the expression of viral ORF7 (PRRSV N) was detected by qRT-PCR (F) and N protein was determined by western blot $(G)$. Data are representative of the results of three independent experiments (means $\pm S E$ ). Significant differences compared with control group are denoted by * $(P<.05)$, ** $(P<.01)$ and $* \star \star ~(P<$ $.001)$.

A

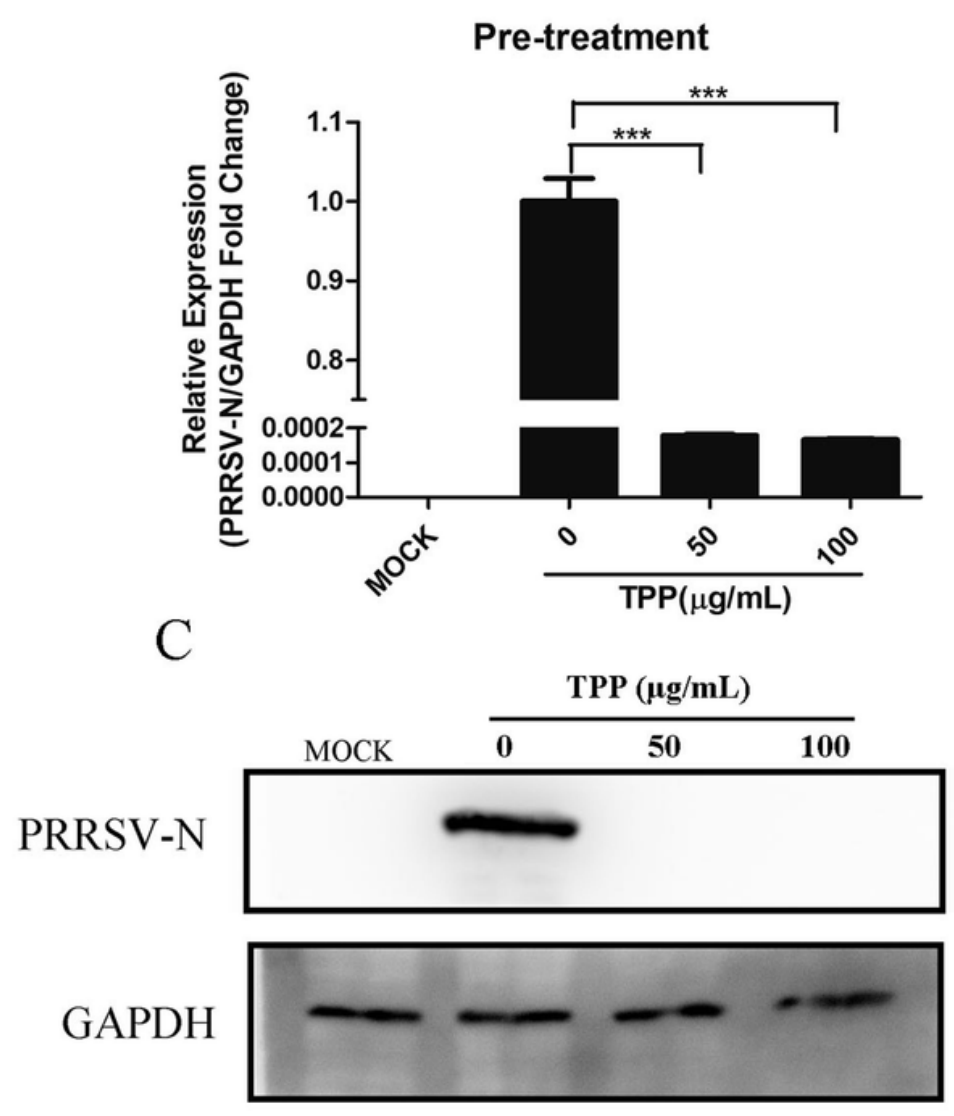

$\mathrm{B}$

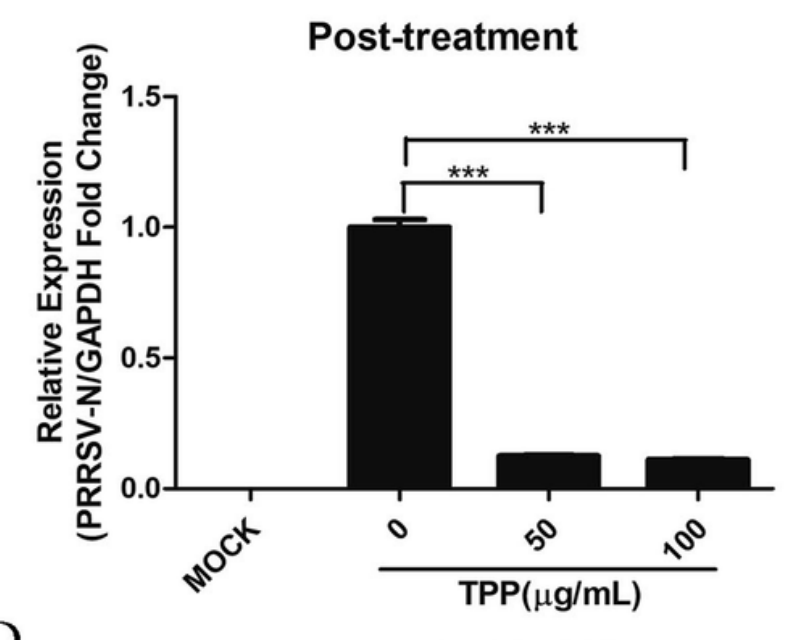

$\mathrm{D}$ TPP $(\mu \mathrm{g} / \mathrm{mL})$

\section{PRRSV-N}

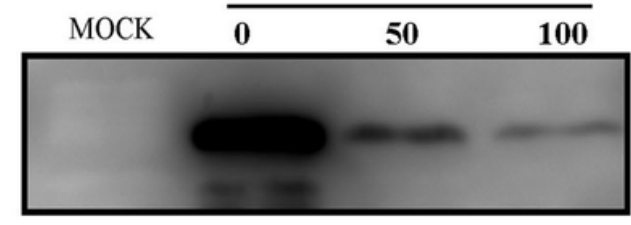

GAPDH

\section{Figure 2}

TPP suppresses PRRSV infection regardless of its pre-treatment and post-treatment. (A and C) Marc-145 cells were pre-treated with different concentrations of TPP for $2 \mathrm{~h}$, then infected with PRRSV-CHR6 for 36 $h$, the expression of viral ORF7 (PRRSV N) was detected by qRT-PCR (A) and viral N protein was determined by western blot analysis (C). (B and D) Marc-145 cells were infected with PRRSV-CHR6 ( $\mathrm{MOI}=$ $0.6)$ for $4 \mathrm{~h}$, and then TPP was added, and cells were incubated for another $36 \mathrm{~h}$, the expression of viral ORF7 (PRRSV N) was detected by qRT-PCR (B) and N protein was determined by western blot (D). Data are representative of the results of three independent experiments (means $\pm S E$ ). Significant differences compared with control group are denoted by * $(P<.05)$, ** $(P<.01)$ and $* \star \star ~(P<.001)$. 
A
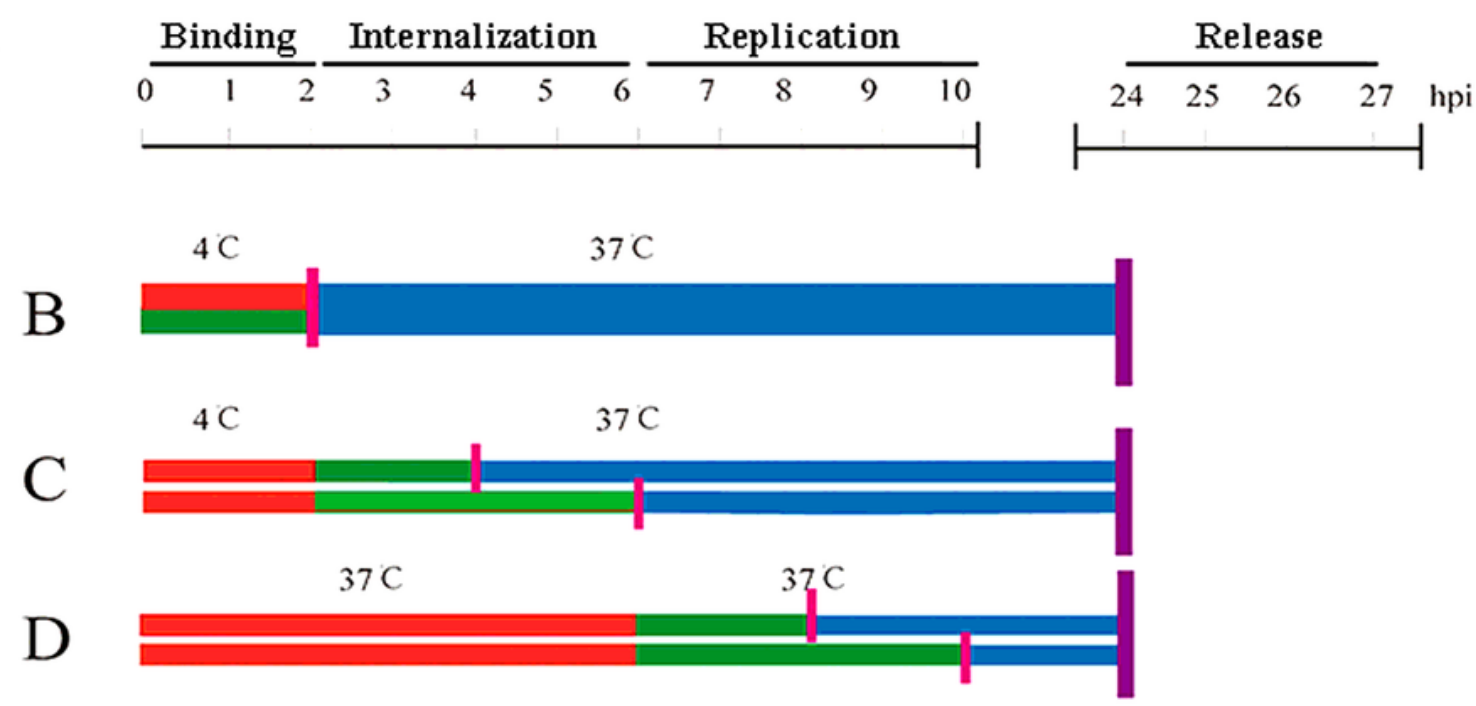

$37 \mathrm{C}$

$37 \mathrm{C}$

E

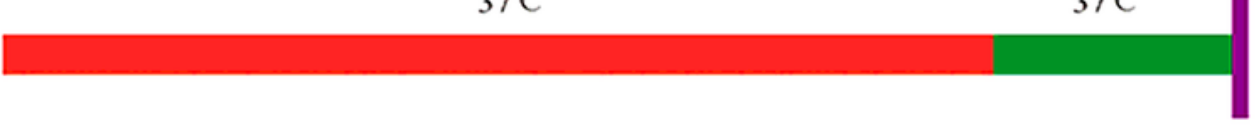

$\square$ :Virus infection $\square$ :TPP treatment $\square$ :Cultured | :Harvest | :Removing TPP

Binding
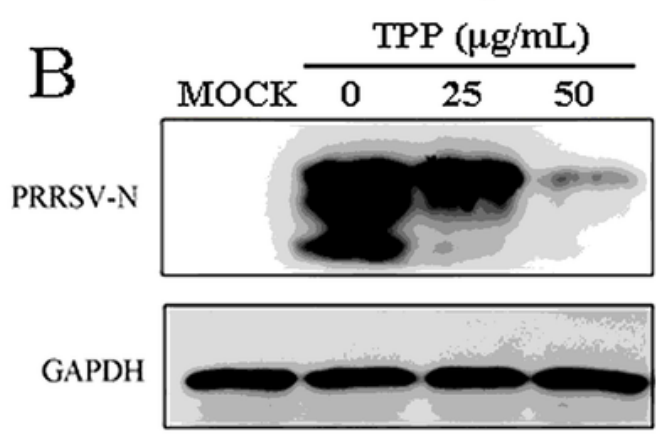

Replication
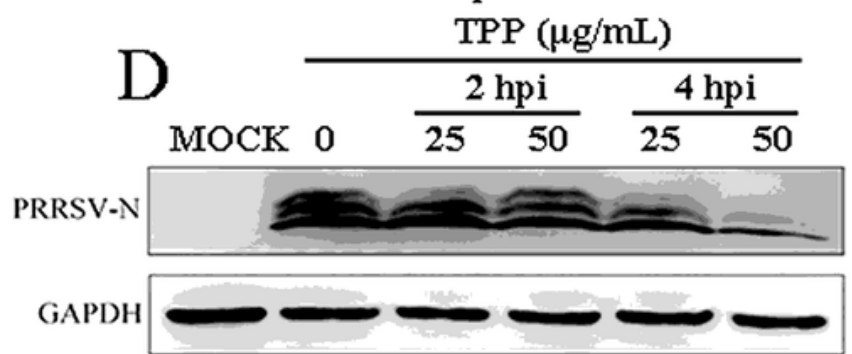

Internalization
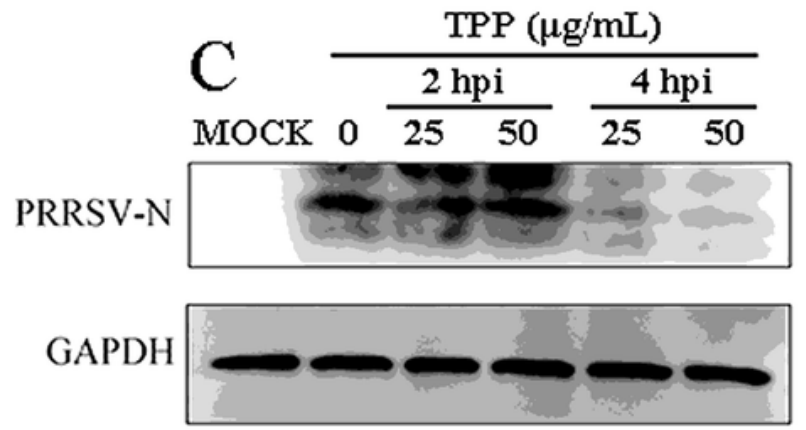

\section{Release}

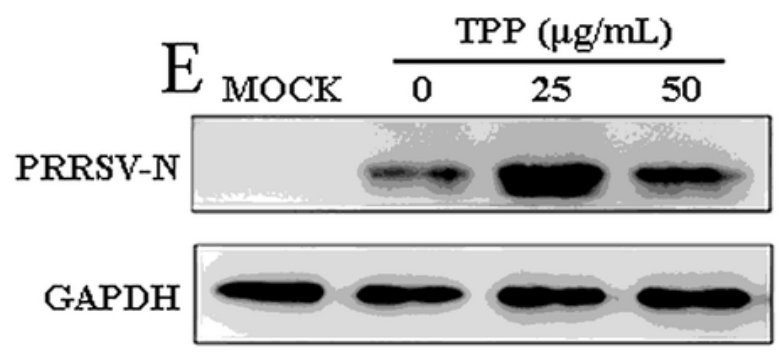

\section{Figure 3}

TPP inhibits PRRSV attachment, entry, and replication, but not release. Marc- 145 cells were infected with PRRSV-CHR6 at an MOI of 0.6, the infected cells were cultured in the presence of various concentrations of TPP and collected at the indicated time-points post infection to determine viral $\mathrm{N}$ protein level by western blot. (A) Different TPP treatment schemes. Red bars represent PRRSV infection period, green bars represent TPP treatment, blue bars represent cell cultured, magenta vertical bars represent removing TPP, 
and purple vertical bars represent cell harvest. (B-E) Viral binding, internalization, replication and release were performed in cells treated as described in A, and then cells were harvested for western blot analysis. Data are representative of the results of three independent experiments.

A

P65

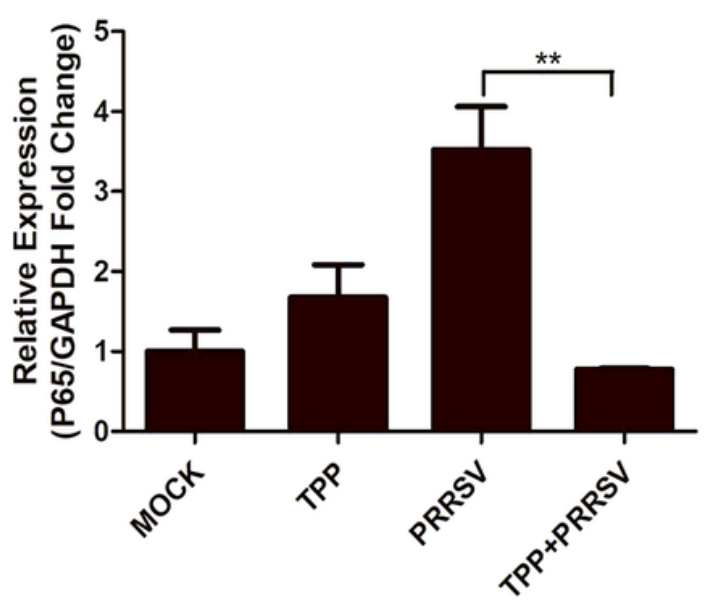

$\mathrm{B}$

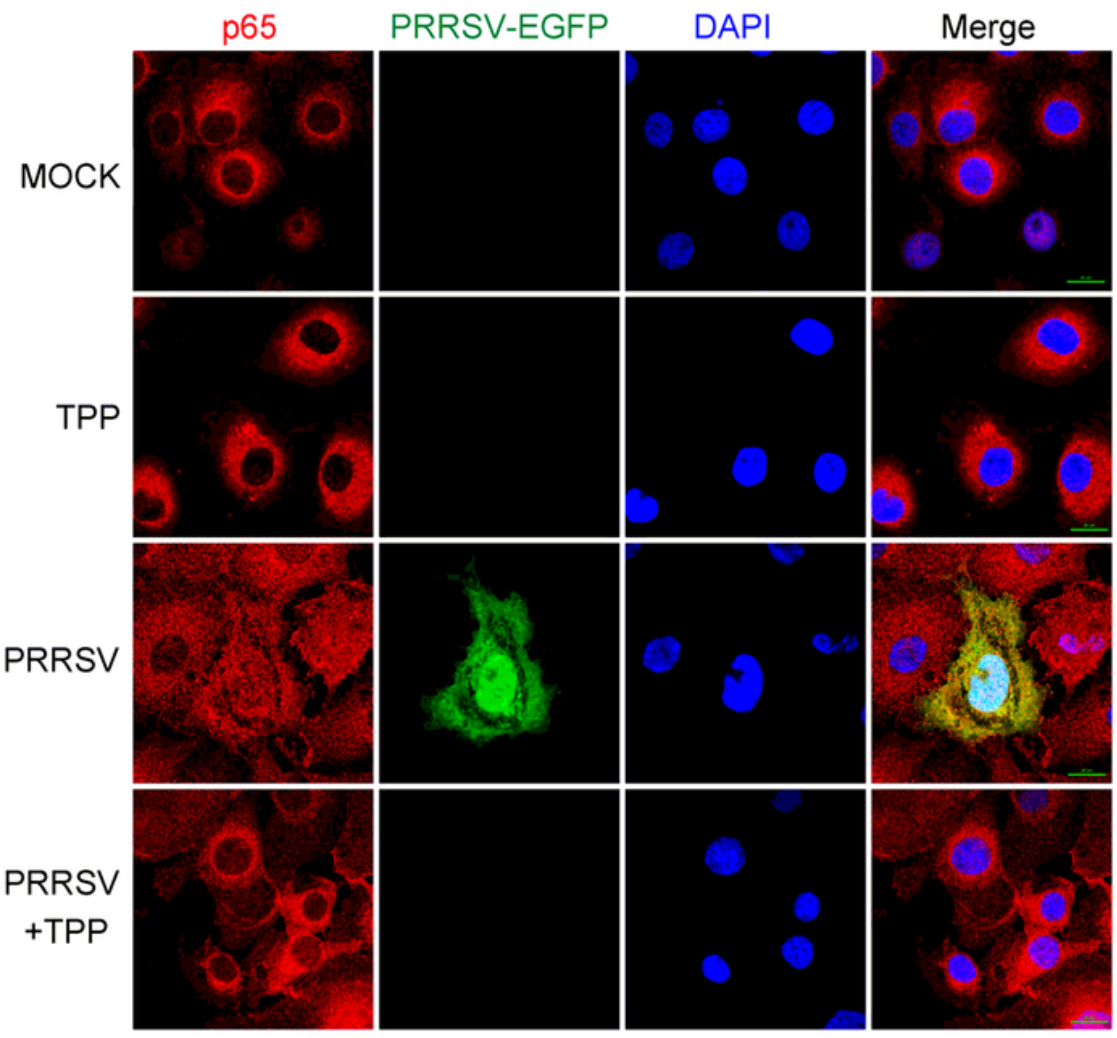

\section{Figure 4}

TPP inhibits NF-KB signaling pathway in PRRSV-infected Marc-145 cells. (A) Marc-145 cells were infected with PRRSV-CHR6 $(\mathrm{MOI}=0.6)$ in the presence or absence of TPP, the mRNA level of p65 was assessed by qRT-PCR. (B) Marc-145 cells were infected with PRRSV-EGFP $(\mathrm{MOI}=0.6)$ in the presence or absence of TPP, IFA for the $\mathrm{p} 65$ protein was performed at $36 \mathrm{hpi}$ using Alexa Fluor 555-conjugated anti-rabbit secondary antibody (red). Nuclei were stained with DAPI (blue). Scale bar, $20 \mu \mathrm{m}$. Data are representative of the results of three independent experiments (means $\pm \mathrm{SE}$ ). Significant differences compared with

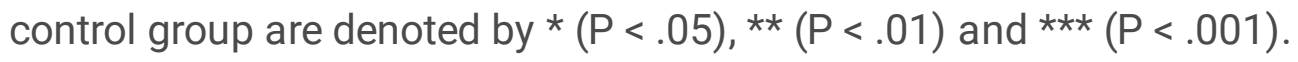




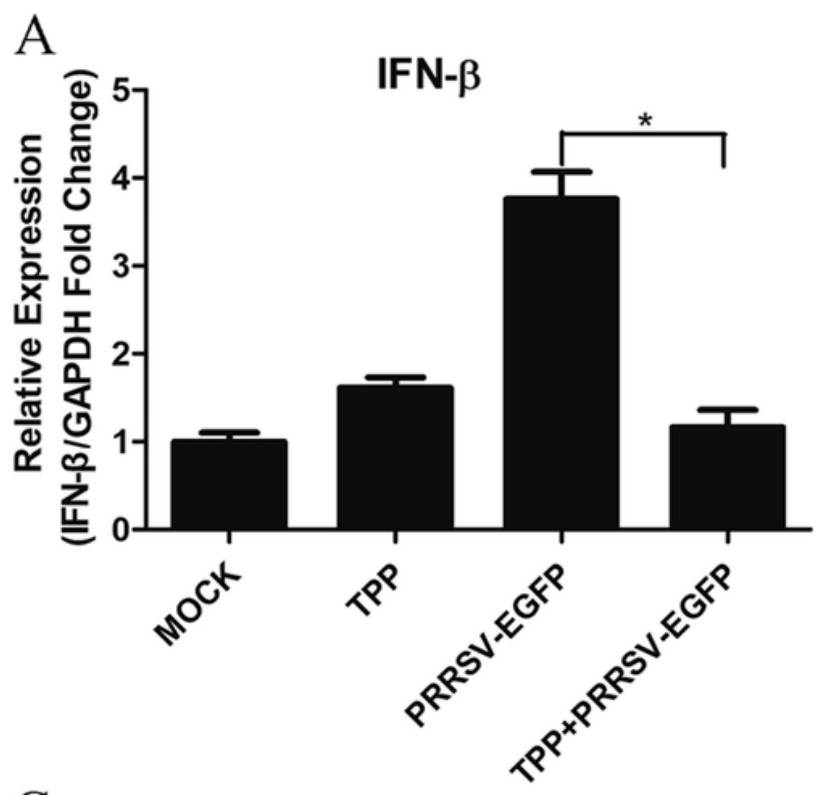

B

IL-6

C
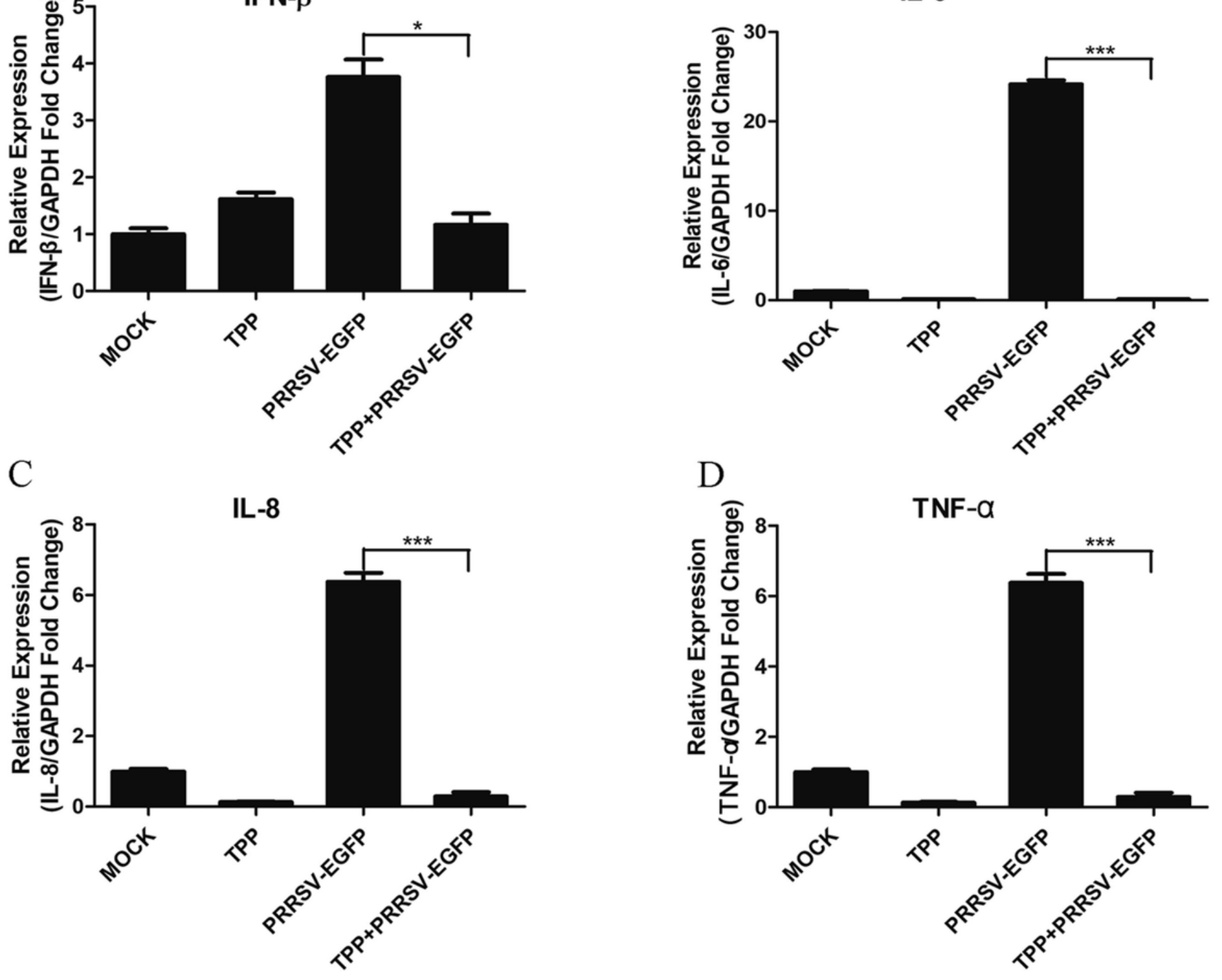

D

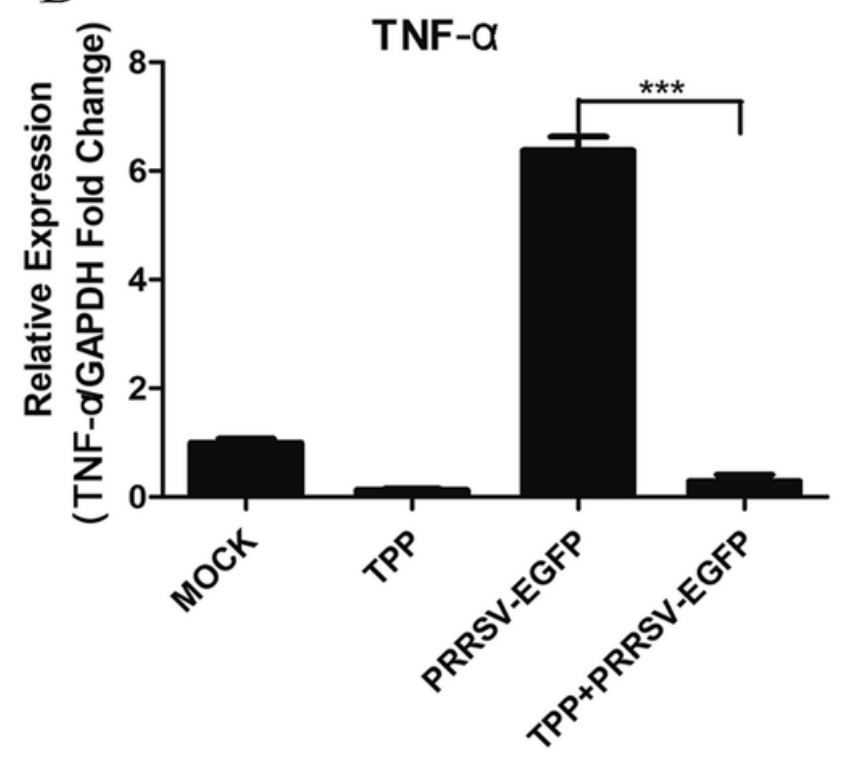

Figure 5

Expression of cytokines in Marc-145 cells treated with TPP. (A - D) Marc-145 cells were mock infected or infected with PRRSV-CHR6 (MOI = 0.6) in the presence or absence of TPP $(50 \mu \mathrm{g} / \mathrm{mL})$ for $12 \mathrm{~h}$. The expression of pro-inflammatory cytokines IFN- $\beta$ (A), IL-6 (B), IL-8 (C) and TNF-a (D) was analyzed using qRT-PCR. Relative expression (fold) in comparison with mock infected cells (set up as 1) is shown. Data are the results of three independent experiments (means \pm SE). Significant differences between PRRSV infected cells and those treated with TPP are denoted by * $(P<.05)$, ** $(P<.01)$ and *** $(P<.001)$. 


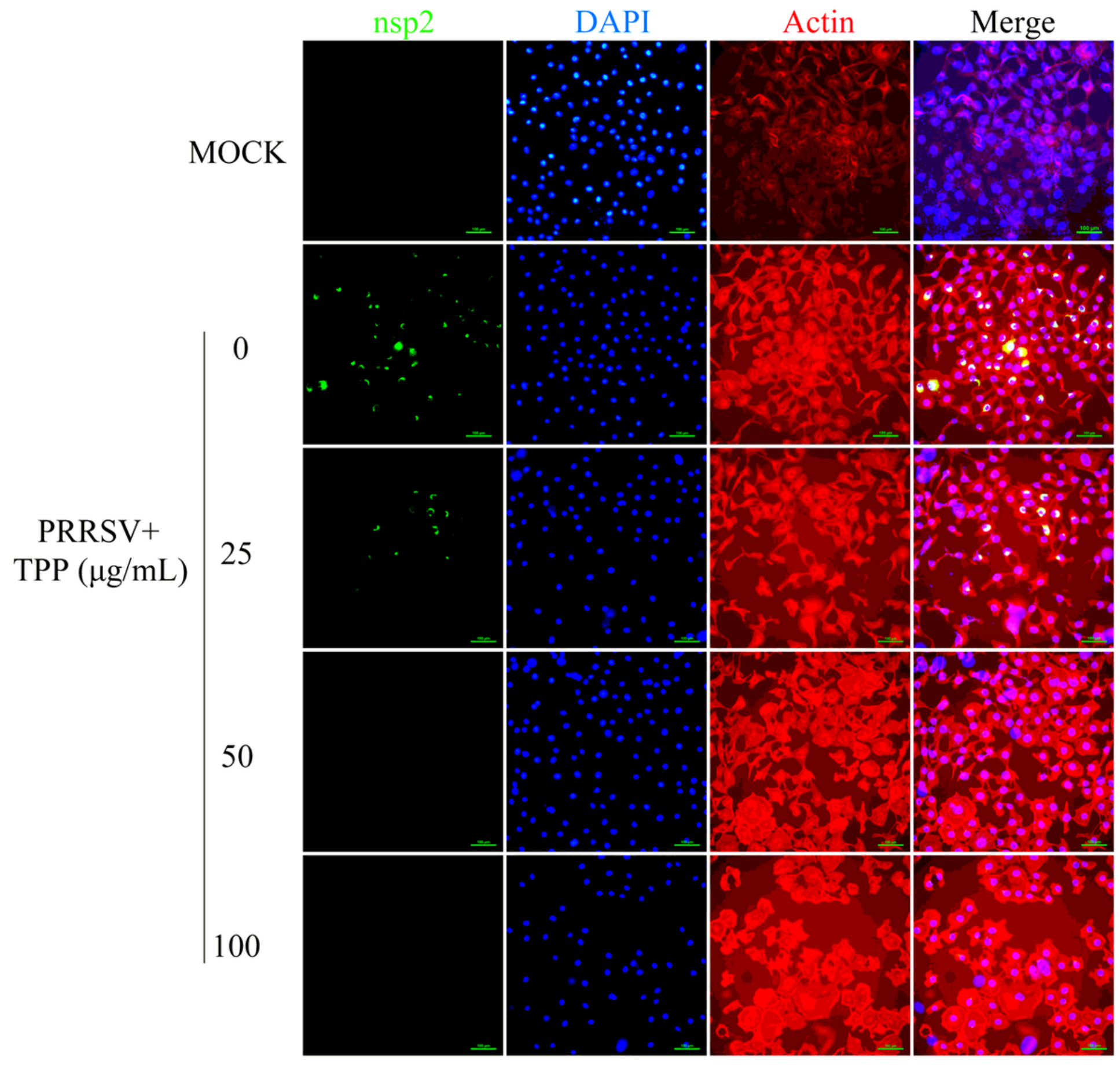

Figure 6

TPP inhibits the synthesis of viral nsp2 in infected Marc-145 cells. Marc-145 cells were infected with PRRSV-CHR6 $(\mathrm{MOI}=0.6)$ for $6 \mathrm{~h}$, then different concentrations of TPP were added, and cells were incubated for another $36 \mathrm{~h}$. IFA for the nsp2 protein of PRRSV was performed using Alexa Fluor 488conjugated anti-mouse secondary antibody (green). The actin protein was stained with Alexa Fluor 555conjugated anti-rabbit secondary antibody (red). Nuclei were stained with DAPI (blue). Scale bar: $100 \mu \mathrm{m}$. 


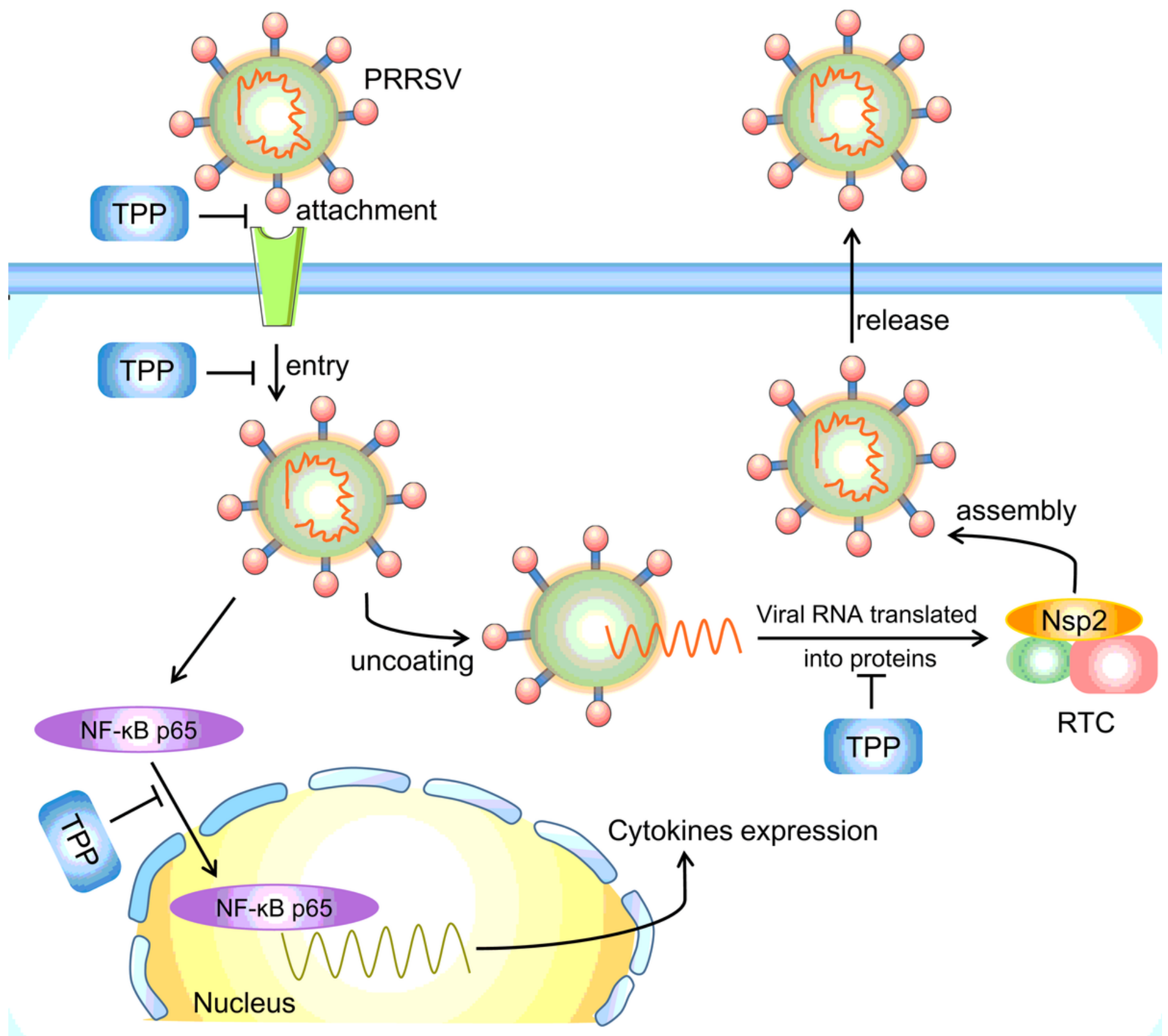

\section{Figure 7}

The schematic diagram of PRRSV inhibition by TPP. On the one hand, TPP blocks the attachment and internalization of PRRSV, or inhibits the assembly of viral RTC after virions enter cells during virus life cycle. On the other hand, TPP is capable of restraining PRRSV-induced translocation of NF-kB p65 into the nucleus, thereby suppressing the expression of cytokines, which may contribute to its inhibition of PRRSV. 


\section{Supplementary Files}

This is a list of supplementary files associated with this preprint. Click to download.

- Additionalfile1.docx 